\title{
THE DEPRECIATION OF HAITIAN CREOLE AND HAITIAN CODE SWITCHING
}

\section{LA DEPRECIACIÓN DEL CREOLE HAITIANO Y EL CAMBIO DE CÓDIGO HAITIANO}

\section{PATRICK PIERRE ${ }^{1}$}

Recepción: 06 de agosto de 2020

Aceptación: 15 de octubre de 2020 



\title{
THE DEPRECIATION OF HAITIAN CREOLE AND HAITIAN CODE SWITCHING
}

\section{LA DEPRECIACIÓN DEL CREOLE HAITIANO Y EL CAMBIO DE CÓDIGO HAITIANO}

patrick Pierre

Key words: Creole language, Haitian Creole, Lexifier, Code-switch, Depreciation.

Palabras clave: Idioma Creole, Creole haitiano, Lexificador, Cambio de código, Depreciación.

\begin{abstract}
The purpose of this paper is to give an overview of Haitian code-switching as a diglossic country and Haitian Creole depreciation as the native language of Haiti. The history of the Haitian Creole language developed by enslaved west African in the plantation of the Island, during the slave rebellion for the revolution after several attempts conspiring for their freedom. After the embarkation of the French Colony in the Island to settle from 1659 till 1804, French has become the language of

dominance, it was the language of the plantations' masters. These two languages have remained the official languages of Haiti in which Haitian people Code-switch when using either French or Haitian Creole. However, Creole has become the language of depreciation, in another term a marginalized language. In this study a qualitative and descriptive analysis have been carried out through social medias such as Instagram, Twitter, Facebook and You-Tube to collect data on Haitian code-switching by observ-
\end{abstract}


ing one of the Haitian Ex-presidents, Mr. Joseph Michel Martelly who is also a famous singer. Some video links will be provided to observe the code-switching of the president Michel Martelly in different situations such as debates with his opponent Mme Mirlande Hyppolite Manigat in 2011 before he won the election, interviews with national and international journalists about political and artistic movement and his performance on stage as a singer.

\section{RESUMEN}

El propósito de esta investigación es dar una descripción general del cambio de código haitiano como país diglósico y la depreciación del Creole haitiano como lenguaje nativo de Haití. La historia del idioma Creole haitiano desarrollada por esclavos africanos occidentales en diversas plantaciones de la isla, durante la rebelión esclavista por la revolución, luego de varios intentos conspirando por su libertad. Una vez que la Colonia Francesa se asentó en la isla desde 1659 hasta 1804, el francés se ha convertido en el idioma dominante, por ser el idioma de los dueños de las plantaciones. Ambos se consideran idiomas oficiales de Haití por lo que al usarse, la gente cambia de código. Sin embargo, el Creole se ha convertido en el idioma de la depreciación, en otras palabras, un idioma marginalizado. En este estudio se ha realizado un análisis cualitativo y descriptivo a través de redes sociales como Instagram, Twitter, YouTube y Facebook para recopilar datos sobre el cambio de código haitiano, mediante la observación de uno de los ex-presidentes haitianos, el Sr. Joseph Michel Martelly, quien es también un cantante famoso. Se proporcionarán algunos enlaces de vídeo para observar el cambio de código del presidente Joseph Michel Martelly en diferentes situaciones como debates con su oponente Mirlande Hyppolite Manigat en 2011 antes de ganar las elecciones, entrevistas con periodistas nacionales e internacionales sobre su labor como político y artista, así como su desempeño en el escenario como cantante. 


\section{INTRODUCTION}

The Haitian language, like others, has suffered the scorn that is too often shown toward its speakers and their culture (Spears \& Berotte Joseph, 2010). However, the main purpose of this study is based on Haitian Creole, as a depreciated language; and Haitian code-switching, between French and Haitian Creole. Haitian Creole, is precisely mentioned, because there are different Creole languages used around the world. Besides Creole has been depreciated during the last decades. Interest has been laid on it as a real language. Creole has an amazing story which lays behind it, by looking back to the history of Creole. It has been developed as a language throughout the era of colonialization. That is to say, that Creole language has its base and root through the European and the African languages, since Creole started to develop during the epoch of slavery. Making reference to the discovery of America, Haiti was the first one to be discovered in December 1492 and baptized with the name of Island of Hispaniola, which means Little Spain, because the Island of Haiti, which is now divided into Dominican Republic in the east and Haiti in the west, was considered "La Perle des Antilles", which means the pearl of the Antilles. (Uzo, 2016) By then, the system of slavery began to emerge by grabbing the native's possessions and made them become slaves, who had to work for the colonists, in their own farms. According to (Arsenault \& Christopher, 2016) "As the indigenous population was dying of abuse and disease, African slaves were brought in; the first 15,000 Africans arrived in 1517". The colonist thought it was necessary to bring those Africans to work in their plantations in order to grow crops to export back to Europe. As slaves were needed, those colonists decided to travel to Africa to purchase slaves. It was when the transatlantic slave trade began during the $15^{\text {th }}$ century. When African men and women with no exception were captured to be sold to those colonists. No one could get support from the authorities because the system was corrupted. They were more interested in their profits rather than in the human values (Manning, 1992). Human beings have turned into goods. African profits in selling human as slaves rose. The authorities, for example, were able to intervene with tolls and taxes in exchange for protection of the trade. Slaves' trading, that is, human beings have become the captives to be sold to masters of the plantations. These capture and distribution structures provided the social pressures encouraging new generations of Africans to participate in enslavement (Manning, 
1992). After all, the captured Africans had to live the worst part of their lives during the voyage and even after they reached land. They could never imagine what they would go through. They had to be transported during months. During this time, they had to endure all kinds of mistreatments. If everyone could see it that way, slavery involved suffering, sacrifice, hate, and acceptance of all kinds. They even sacrifice their own children involuntarily in their attacks to slave raiders. They could not think of any rescue, hope, or voice to cry. Their unique hope was to wait until fate determines what it preserved for their lives.

As the African slaves came from different tribes, different dialects were spoken in the plantations. French was spoken by the Colonists, which caused the slaves to be exposed to French and used it to communicate with their masters.

It has been suggested that with the arrival of fresh massive contingents of African slaves during the peak years of the expansion of the plantations in the contact language went through various stages of development, to the point of becoming the shared means of communication in the slave population (Chaudenson, 1979, p. 57).

The slaves from different tribes started to use that dialect to communi- cate with each other, by that time. It was of course, considered as a dialect, because back then, there was no structure created yet for its use and it also allowed them to do, what it is called in sociolinguistics, code-switching. The Creole language is formed and derived from different other languages, such as: French, English, the African Dialects, Spanish, Portuguese, etc. Haiti has evolved in a very different direction to get their freedom, which was gotten by rebelling against their masters. They organized secret meeting, since they couldn't speak the same language. They had to use this new dialect in order to understand each other's ideas and plans. Then, Creole language started to develop. When a language is called Creole, linguists are referring to a new language that emerged out of language contact situation, in which the speakers had limited resources for learning each other's language(s) (Spears \& Berotte, 2012, p. 8). Analyzing the languages mentioned previously, the basic lexicon of Creole language is typical but it is not always derived from a colonial language, which was often a dialect of a European language. Something important to know, is that the language that is the source of the vocabulary is called the lexifier or superstrate.

Regarding the Creole spoken in different places of the world, Haiti has remained one of the countries where 
Creole is the most spoken language, and somehow it is sometimes called "Haitian Creole". The purpose of this study is to reflect on how Creole has been degraded by a marginalized group, and how it is code-switched into French, in Haitian conversation. An observation will be carried out on the previous Haitian president named Joseph Michel Martelly to analyze how Haitian people code-switch in both Creole and French. Information about his personal life will be mentioned as a Haitian citizen and also his life, as one of the most famous Haitian singers.

\section{BACKGROUND OF HAITIAN CREOLE}

Since Haiti is a diglossic country. "A geographical point of view, most Creoles are spoken in areas of colonization fairly close to the equator" (Bakker, 2004, p. 2). Before the discovery of the Island there were the Indigenous and aborigines' ethnic groups settlements, right after the Island had become colonized to exploit its wealth, where strong workers were needed for the exploitation. Back then, in the $17^{\text {th }}$ century, there was a deal named "Black trade" or "trade of slaves", which was to bring some Africans to Haiti in order to work on their lands. There was a specific place, where they were taken, to be sold and then became slaves. This was named "Croix-des-Bossales". The Croix-des-Bossales market is historically the oldest market where slaves freshly landed from slave ships and were sold. It was also the place of agricultural products supply. But where does the word "Bossales" come from? The slaves, who arrived from Africa to the bay of Port-au-Prince the capital of Haiti by boat, were called "dirty handsome" or "dirty skin". The word bossale is, precisely, the slaves of Africa, who were brought for slave trade, to the plantations of Haiti and who, based on their struggles, sufferings and hopes, were also called the wild.

For the American people (USAID, 2018), since the Island of Santo Domingo was a major producer of coffee, tobacco and sugar, Croix-des-Bossales was the largest food and trade market at the time. As time went by, the slaves started to rebel, and they were immediately divided into different groups, so that they could not be able to communicate with each another, and it was when, the Haitian Creole was born (Bonenfant, 2011). Haitian Creole, a French-based vernacular language, was developed in the late $17^{\text {th }}$ and the early 18th centuries. It developed mainly on the sugar- 
cane plantations of Haiti, from contacts between French colonists and African slaves. However, the language also has some words linked to the primitive language of the native Indian people from India, who settle in Haiti before the discovery of Haiti by Columbus, which was called the "Quisqueya or Bohio". All Haitian schoolchildren learned in their geography and history textbooks that our Island was originally called "Haiti, Quisqueya or Bohio" (Doucet, 2011) and that these were the names used by the Arawak (or Taino) aborigines inhabiting the Island, when Christopher Columbus arrived. For most Dominican historians, the Taino name of the island is Haiti, while for others, the original name would rather be "Quisqueya or Bohio". These Taino names would, therefore, have a character of original authenticity and refer, in the popular imagination, to an idyllic past when the Island was the "Paradise of the Indians".

Then the Conquest and Colonization came, and within this, the names imposed by the Europeans:

La Espanola, Hispaniola, Santo Domingo imposed by the Spaniards and Saint-Domingue imposed by the French. A convention, tacit among some historians, is that these different names are used to designate different periods in the history of the
Island, pre-colonies, colonies and post-colonies (Hispaniola, 2017).

However, this logic does not always apply. For example, in some Dominican textbooks, the Island is simply called "Isla de Santo Domingo", although it comes from the pre-Columbian period or more remote geological periods. Another source for researching the meaning of the word Haiti is the African tradition along with the Haitian language.

The history of the Haitian-Creole language has proven that the existence of the language is uncertain during the Pre-Columbian era, because the Taino Indians, who migrated from India to Haiti, were the first inhabitants of this island. And they had their own language, which was totally different from Haitian-Creole, even though few Indian words, such as: roukou (wookoo), banbou (bamboo), mabouya (mabooya) are still being used in the language. "The language of the inhabitants of Haiti follows the language universals components (lexicon, morphology, semantics and syntax) like all human languages" (Bonenfant, 2011). It is now widespread among both linguists and non-linguists, that Creole languages form an exceptional class on phylogenetic and/or typological grounds. It also has non-linguistic (sociological) implications, such as the claim that Creole languages are a "handicap" for their speak- 
ers, which has undermined the role that Creoles should play in the education and socioeconomic development of monolingual Creolophones (Degraff, 2005).

\section{LEXIFIERS}

The grammatical structure of a Creole often deviates, considerably, from that of its lexifier. The question arises whether there was, or is indeed, a qualitative difference between language learning involved in the creation of a Creole and first language learning (Pieter \& Norval, 1986, p. 232). The answer to this question will be extremely difficult, but taking into consideration the Genesis of Creole, there are neither linguistic nor historical reasons, for assuming that there was a qualitative difference between the language learning of the first native speakers of Haitian and first language learning, under usual circumstances. As Haitian Creole was, clandestinely, developing French words started to be modified to give birth to Creole. Creolists disagree on the reasons why there are differences between Creole and lexifier structures. Some emphasize that Creoles are continuations of the lexifiers, and those adhere to this idea, which are called superstrates, in literature. Others stress the influence of speakers of other languages, for example Papuan or Oceanic languages, in the case of Pacific Creoles. and the mother tongues of Africans, including slaves, and the Caribbean, English, French and Spanish, as lexifiers. Such languages are called substrates if they are no longer spoken in the Creole- speaking communities. According to Michaelis (2008), cited in (Bakker \& Daval-Markussen, 2004). "A number of structural features found in Creole may be due to universals, for instance statistical universal such as patterns of grammaticalization, the result of which may differ among Creoles compared to non-Creoles".

\section{SAMPLE TEXT IN HAITIAN CREOLE}

Tout moun fèt lib, egal ego pou diyite kou wè dwa. Nou gen la rezon ak la konsyans epi nou fèt pou nou aji youn ak lot ak yon lespri fwatènite. 


\section{TRANSLATION}

All human beings are born free and equal in dignity and rights. They are endowed with reason and conscience and should act towards one another in a spirit of brotherhood (Article 1 of the Universal Declaration of Human Rights).

\section{CODE-SWITCH}

Since Haiti is a diglossic country, the term code-switching occurs frequently in the language; however, it does not mean that Haitian people only code-switch in French and Creole, whether they are in or out Haiti. According to this view (Dejean, 2015), Haitian Creole is considered to be nothing more than a non-standard form of French. Thus, it is interesting to see how Haitian people code-switch according to their needs in situational and social factors. As mentioned earlier, the purpose of this study is to observe how Haitian Creole has been devalued and the way Haitian people code-switch between each other when two or a group of Haitians are interacting. Talking about Creole,

In 1804, Haiti experienced its glorious beginning as the first independent black nation in the Western Hemisphere; but the leaders did not see fit to provide a place for the creole language in its legal, political, and edu- cational institutions, in fact, although Creole was intertwined with the sociocultural practices of the Voodoo religion, instrumental in the Haitian Revolution, and also by far the most widespread language in colonial times, its role, status, and use have always been controversial (Alcenat, 2018).

Well, Creole and French, which has long been more valued by the Haitian elite, have been linked throughout Haitian history in a project of domination. In spite of this, it is recognized and admitted that Creole has been a discriminated language in Haiti. One of the reasons is the fact that, in Haiti, there is a strong dominant social class. This means, the high social class known as the elite, has been subjected to eliminate it. It is claimed that Creole is part of Haitian identity because it tells who they are and where they are from. It is the language that flows in Haitians' veins. However, 
during the $21^{\text {st }}$ century, Creole has lived a great transformation. Now, it is considered as the first, national and official language of Haiti. Every single Haitian must be proud to speak Creole everywhere.
Thus, Creole and French have become a brother and sister language. Nowadays, there is no single Haitian who uses the Creole without using a French word and vice versa.

\section{DEPRECIATION}

The Haitian Creole, which is the mother tongue of all the Haitian people: born, raised and lived in Haiti, has been depreciated and devalued, that is, it has been stigmatized in the society. In addition to this, there are some groups of people who take the history for granted, which means, that to ignore the Haitian Creole language is to ignore the Haitian history. That is to say, the existence of Haitian Creole has a lot to do with Haitian history. If Haitian people are free today, it is a due to Creole, because it was the language they employed to communicate and conspire against their masters for freedom. At this point, to consider factors or reasons why people underestimate this wonderful heritage, left by the ancestors to the Haitian people, may be said that it is something insane, illogical, absurd and thankless. In Haiti, as mentioned previously, Creole is somehow, a language of no value as many people think. They think that using this language will take you to nowhere, which is wrong. For example, if two Haitian people go to an institutional setting to do something as paperwork, the one that speaks in French will probably be the one assisted first. Since French has prevailed, some people even forget that historically, Creole was the language which led Haitians to the path of being free from the slavery. Haiti has been recognized, as the first country with afro-americans in the world, which got its independence in 1804. Creole was the language, secretly used, when they had to meet to conspire against their Masters, for the revolution.

Haitian Creole is predominantly used by most of the population. It is the language used in everyday conversation. It tells Haitians exactly who they are, their origins, their culture, and their identity. It is the language used to express: their feelings, happiness, and anger, socially talking. On the other hand, when you refer to: educational, political and economic factors, Creole has indeed no value for some people because this is how it has been marginalized since the beginning. This is something 
that Haitians should not think about if they speak Creole. Some people think, they are not educated people, which is not true. This is a crucial situation which the language is going through. And it makes you believe that if you are not educated or illustrated, you are not able to occupy any important position to serve the country. Well, it is just a matter of how well you can speak French without taking into account how competent that person can be to serve a commu- nity. This is how these people are really mistaken, since they only focus on good speech but not on positive actions. To show you how Creole was not regarded as an important language, it was not an official language, "as French was. It was not until 1987, that Creole was granted official status" (Holmes, 2013, p. 103). Every Haitian patriot inside and outside Haiti should feel proud to use it and represent that wonderful language as part of their identity.

\section{METHODOLOGY}

The research method used for this study is descriptive and qualitative. Data was collected from March 2020 by observing the former Haitian president's speech through You-Tube videos, which are listed in the chart below.

\begin{tabular}{|l|l|l|}
\hline No. & \multicolumn{1}{|c|}{ LINKS } & \multicolumn{1}{c|}{ TOPICS } \\
\hline 1 & https://www.youtube.com/watch?v=kMW640I-rol & Video clip after leaving the presidential mandate \\
\hline 2 & https://www.youtube.com/watch?v=d-laZN-rl/8w & Video clip with code-switch in French and Creole \\
\hline 3 & $\begin{array}{l}\text { https://www.youtube.com/watch?v=MY5wITL- } \\
4 \mathrm{~mm} 4\end{array}$ & Concert in Chile in 2017 \\
\hline 4 & https://www.youtube.com/watch?v=F1kGpNB_Bvg & Musical Interview of Michel Martelly with his three sons \\
\hline 5 & $\begin{array}{l}\text { https://www.youtube.com/watch?- } \\
\text { v=d-HpuMhWzkA }\end{array}$ & $\begin{array}{l}\text { Interview with the president Michel Martelly in a visit to Paris to } \\
\text { talk about the earthquake which affected the country }\end{array}$ \\
\hline 6 & https://www.youtube.com/watch?v=r0qAW4VIC48 & $\begin{array}{l}\text { Interview with the president Michel Martelly about his plan as a } \\
\text { president with a Canadian Journalist }\end{array}$ \\
\hline 7 & https://www.youtube.com/watch?v=evUnps80qJl & $\begin{array}{l}\text { Debate with both candidates Michel Martelly and Mrs. Mirlande } \\
\text { Manigat before the elections in 2011with code-switching }\end{array}$ \\
\hline
\end{tabular}


As it can be observed, in the first link, Michel Martelly first released his video clip, as an artist, months after he left the five years mandate. In the second link, there is also a video clip where he sings expressing his feelings while he is code-switching in both French and Creole. In the third video, he was in a concert in Chile, singing for the Haitian people living in Chile, where it can be seen how laid-back he is when performing on stage. In the fourth link, Michel Martelly's three sons are having an interview in a show called CHOKARELLA. In this interview, Michel was also invited; nevertheless, his sons did not know that he was going to be there in the show, as they are famous singers as well as their father. They were invited to talk about their new album. On the other hand, in the fifth link, Michel Martelly, as the president of Haiti, was having an interview with a French Radio station in Paris-France. He talked about the economic situation in Haiti after the earthquake in 2010. Also, in the sixth link, the president Martelly was accompanied with some police, officials and ministers of his government, in a province of the country. He was interviewed by a Canadian journalist. The interview was about his plans and the things he had done during the first year of his mandate. Regarding the last link, it is a debate between Michel Martelly with his opponent Madam Lesly Manigat, where code-switching in French and Creole was used.

This study was selected to analyze the president discourse in different contexts. This analysis was be based on male sociolinguistic discourse patterns. Michel was chosen, purposely, to make the speech observation on code-switching, because he is known as one of a Haitian legendary. Referring to legendary, there are two aspects that must be taken into account: his political and artistic aspects. Also, on stage performance will be observed through photographs collection from google. 


\section{PARTICIPANTS/SAMPLE}

Figure 1. Michel Martelly in 2011

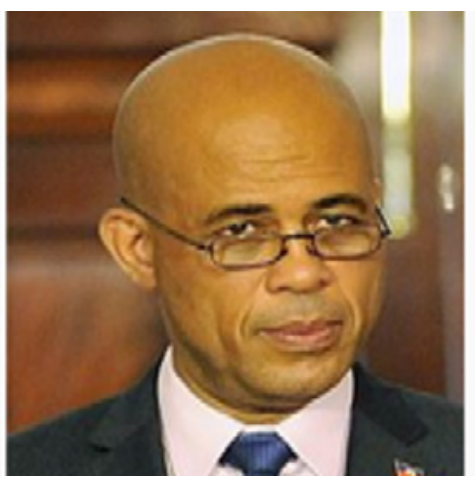

Source: Wikipedia (2020)

Michel Martelly, better known as "Sweet Micky", was born on February 12, 1961 in Port-au-Prince, Haiti, he is a Haitian performing and recording artist, composer, and musical sociopolitical activist. Martelly served as President of Haiti after winning the presidential election in 2011. Martelly is more popularly and affectionately known as "Sweet Micky," a moniker sometimes used interchangeably to refer to himself as well as his band

(with original members, guitar player Alex Tropnas and bass player Welton Desire). As a politician, you can clearly clear to distinguish that he code-switches a lot when he is giving a public speech. Normally, he tends to code-switch more when he is being interviewed in Creole, which means, he tries to use a lot of French words while he syntactically uses Creole; however, it can be seen that when he is being interviewed in French, his code-switching is reduced.

Being a singer has made him gain the popularity he needed to become the president. In this case, we are not talking about code-switching, because of course, his lyrics have a mix of Creole, French, and sometimes English, as well. However, in some of his songs he has texts written only in French, Creole and English. In his interviews, as an artist, code-switching is more frequent in his speech. And of course, when he performs, he code-switches depending on the audience.

\section{FINDINGS}

Further details are given here to understand better the information found during the observation of the former Haitian president's code-switching, in both French and Creole, as two official languages of Haiti. As mention earlier, before he became the president of Hai$\mathrm{ti}$, the population proclaimed him as the 
president of "Haitian Kompa" which is the typical music of Haiti.

This link is about a video clip released in 2019 after leaving the power titled "Manvi mangew" It means: "I feel like eating you".

https://www.youtube.com/watch?v=kMW640l-rol

In this video clip he is singing in Creole expressing his feelings. There is no code-switching in this clip.
In this link, you can see that one of his songs titled "Fragile" from his album "I don't care" in 1993, he is singing in both French and Creole. At the beginning of the video $0.45 \mathrm{~s}$ to $1 \mathrm{mn} .35 \mathrm{~s}$ he is singing in French, then he code-switches in Creole until $1 \mathrm{mn} 56$, then back to French, and vice versa.

https://www.youtube.com/watch?v=d-laZN-rl8w

\section{TRANSCRIPT OF CODE-SWITCHING}

French: Elle a des yeux couleur d'argent, elle est fragile comme un enfant, tu feras de l'amour et d'affection. Son regard transpire l'innonce d'un coeur qui ne peut pas soufrire, mais qui plutôt voudrait sourire. Et moi le soir quand je m'en dorme je pense à ce petit coeur frivol et je voudrais toucher son corps.

Creole: Pa manyen mwen fò, pa metem sou a, pa manyen mwen la a...

Figure 2. Michel Martelly performing on stage as a singer

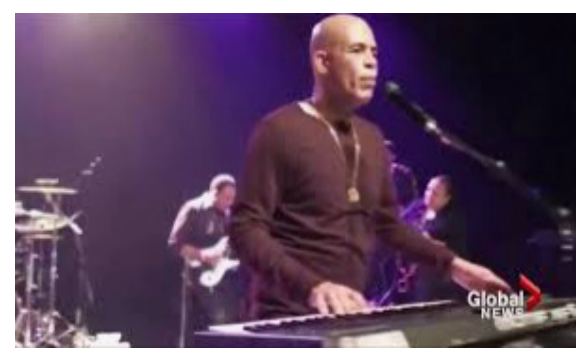

Source: Staff (2019)
Music has given him a great popularity; however, he has been strictly criticized nationally and internationally for his behavior as a singer, regardless his attitude, this did not prevent him from becoming a president of the nation. When he is on stage performing as a singer, it can be noticed that he has a different personality. It is not easy to believe but it is true. When he is on stage, performing according to the words he uses, you can ask yourself How he could have become the president of a nation?. It should be admitted that his style has also given him a lot of fame. Many people like him for the way he sees things- He is a real and authentic person. And most of the people like this about him.

In this link below, he was performing in Chile in December 2017, where you can see some of the situations men- 
tioned above. He gave positive advice to all the Haitian people living in Chile and told them to behave positively.

https://www.youtube.com/watch?v=MY5wITL4mm4

Figure 3. Festival months after leaving his presidency in 2016

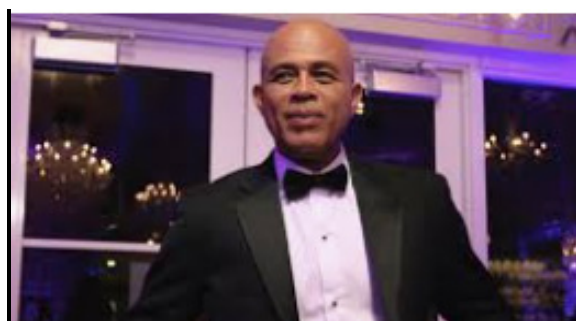

Source: Reinartz (2019)

In this link below, there is an interview with Michel Martelly, "Sweet Micky" accompanied with his three sons. They are talking about their projects about music. And he is also talking about the experiences he had had with his sons in different occasions, traveling from city to city, for festivals and concerts. He also mentions, that as a hardworking person, he had to teach his sons to work hard and to be responsible in their lives and in decisions making. He is being interviewed by a journalist named Karel, one of the well-known Journalist in Haiti. This interview was in Creole; however, there were some code-switched French words such as: voilà pourquoi, comme si, parce que, que ce soit, en parlant de, etc. https://www.youtube.com/watch?v=F1kGpNB Bvg

\section{Interview with Michel Martelly as president}

Figure 4. The President of Haiti with the president of the United States

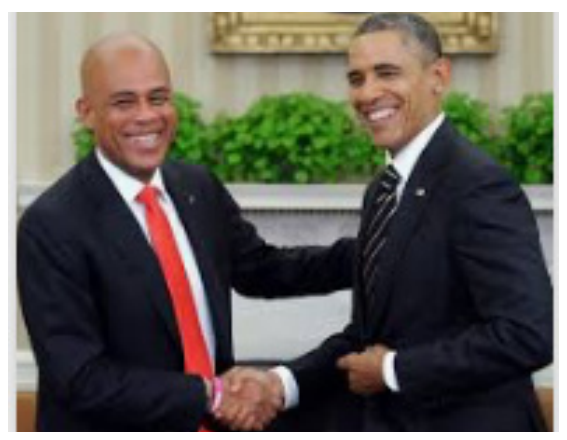

Source: Clark \& Charles (2014)

This link shows an interview in French with the president Michel Martelly on a French channel, with no code-switching. Having an interview on a French channel means that code-switching is not likely to happen because the interviewer does not speak any Creole; however, if there is a term with no translation, quotation can be used for reference, whereas when it is an interview with Haitian national channel code-switch usually happens.

https://www.youtube.com/watch?v=d-HpuMhWzkA

In this link below you can observe that in this interview there is no code-switching because he was interviewed by a Canadian Journalist. https://www.youtube.com/watch?v=r0qAW4VIC48 
This link shows that there is a debate between the two candidates before the election in 2011. In this debate, a great range of code-switching by the President Michel Martelly and some journalists when answering the questions, can be noticed.

https://www.youtube.com/watch?v=evUnps80qJ

In this debate, in minute 1:30s, the Journalist asked him a question about how he could lead a country if he could lose three Houses in Miami for not being able to manage his assets. However, in the journalist question, it can be clearly heard, both French and Creole. As he answered the questions with code-switching, he did not deny that he has lost the houses, but he mentioned that it is normal because everyone make mistakes in this life, even Donald Trump has lost some of his assets. Besides he said he is not responsible for his assets. His Lawyer Mrs. Natasha Magloire is responsible for managing all his assets, so he told the journalist if he needs extra details, he could contact his lawyer. Also, he said that losing three houses will not make any differences in his life. As a singer, he has had some successful concerts and he has had some bad ones, as well. This is the way life is. He mentioned that life goes on and he is ready to become the president of Haiti and change the country.

\section{The transcript of example of code-} switch from the link attached above

Creole Martelly: Rapidman map di ke o mwen, menm lè kob sa a mwen te idantifye a li pa disponib e mwen gen yon plan poum te retire anba tant e mwen pat mansyone lot kòb nou idantifye deja ki evalye a \$10 milion le mwa ke nou ka kreye.

French Martelly: Nous même a travers des revenus de l'état.

Creole Martelly: Sa se youn, e map profite di nou ke travay ke map fè a kòm madam Manigat te kontan poum pot fich yo pou li. Mwen ka di nou se model travay yo nou konmanse fè kounye a poun ka konen kòm resous poun ka travay.

\section{Journalist French and Creole:} Bon map tou presize ke mwen pa yon redackè chef de Journal le maten, je suis plutôt directeur general du journal, c'est une precision importante, mwen gen yon question pou Mesye Martelly, eeee gen anpil chif ki tonbe la a, en fait ou pale de yon bonne gestion de ressource de l'état pouw ka jwenn anpil kob pouw fè saw bezwen fè yo notamment à partir des cent premiers jours. Genyon article ki sortir nan Miami le 7 Mars, voici l'article, ki fait état de Mesye Martelly qui n'est pas tout à faire un bon gestionnaire de ces propres avoirs financiers e ke 3 mezon labank oblige sezi, ou pa peye normal- 
man, ou just pati u pa al negosye ak bank la, menm lopital tal fè pouswit kont ou menm ou pa al peye bil à partir de ces donnés disponibles de vos propres gestions de vos propres affaires, ki garanti nou genyen tout lagen sa yo, tout fich sa yo wap pale ou pral jwenn yo, ou pral gere yo bien dès qu'il s'agit des affaires de l'état?

\section{Creole and French Martelly:}

Très facile, premièrement la question de I'hopitale est fausse et la question des investissments elle est vraie, fòm diw ke d'ailleurs pour pouvoir investir dans trois maisons ça coût beaucoup et Donald Trump l'a fait, il a perdu beaucoup d'avoir.

There was no code-switching in the first question he answered, in this debate; however, in the second question he started talking in Creole, and suddenly, he code-switches in French. Of course, the situation started to be intense and it can be noticed a repeated use of Creole and French. If you watch the video carefully you can see the behavior of Mr.

Michel Martelly compared to his opponent Mrs. Mirlande Manigat, who is completely different. In addition to this, Mirlande Manigat was the wife of an ex-president named Leslie Manigat, known as one of the most intellectual Haitians, who was also a writer. This debate was mainly in Creole, where the $35 \%$ of French is used.

In this link he is being criticized by some Canadian authorities because he was invited to a concert, but it was argued that such a person cannot come to perform in Canada. His reputation has been seen very negatively, in some occasions, for some inappropriate words he usually uses when he addresses the audience. However, he himself stated that he has a different audience. He has texts for different audiences, depending on where he has to perform.

https://www.facebook.com/tij18h/videos/339381650038949/

In order to collect data for this project, based on Creole language and code-switching between French and Haitian Creole, it would be better to do a field analysis on the language being used in Haiti and observe how different Haitians code-switch. That's why, the ex-president of Haiti Joseph Michel Martelly was chosen, so that different area of his use of the language could be observed, whether as a president or singer on YouTube, Tweeter, Facebook, and Instagram. 


\section{CONCLUSION}

In general, it is important to know that Haiti is not the only country where Creole language is spoken. It is one of the languages spoken in many other countries around the world, in different forms like: Pidgin, Patois in Jamaica, Louisiana Creole, Guyanese Creole, Hawaiian Creole, etc.

According to Bretons, (1996) cited in Bonenfant, (2011) the Haitian Creole language was developed by the enslaved West Africans in order to communicate among themselves. That is to say, that the enslaved West Africans were not able to comprehend the different languages such as French, English, and Spanish used by slave owners. The reason for Creole to derive from different languages is that it comes from different languages that were used: first, from the language of a colony of Spain; then from the English of England and in the end French, spoken in France. A misundersting bunch of words in Spanish, French and English became Creole words. For instance, word "bucket" in Creole becomes "bokit", which means the linguistics link between Haitian Creole and English. It can be found in semantics, morphology, phonology, and lexicon.

Creole can be considered the linguistic product of two or more languages that were combined to form a language that enables people from different groups to communicate. In that epoch, the Creole used in the plantations, was more likely a lingua franca, to facilitate the enslaved from West Africa to communicate. In this article, it can be noticed that a trajectory of the language from the dawn until now, which should be very appreciated; unfortunately, this is not the case. It has been devalued and stepped on as if it were a language of no history and background. It is very common to find, English expressions used as sentence fillers, such as: I mean, you know, you see what I mean, in the Creole speech of Haitians. On the other hand, talking about code-switching between French and Haitian Creole, Haitians tend to code-switch in every sentence they use. For example, Salut or Bonjour is a French word you might hear when Haitians greet each other; then they might keep on saying "comment vas tu?", "comment ça va?", "tú vas bien?", which means how are you?, usually to start a conversation even though they are talking in Creole. Depending on the settings or social factors, a variety of French and Creole can be heard. The Haitian language is the linguistic horizon of the Haitian people, which must make every single Haitian on earth proud when using this wonderful language. 


\section{REFERENCES}

Alcenat, W. (2018). To Trasnplant in Alien Soil: Race, Nation, Citizenship, and the Idea of Emigration in the Revolution Atlantic. Journal of Transnational American Studies.

Arsenault, N., \& Christopher, R. (2016). Africa Enslaved: A Curriculum Unit on Comparative Slave Systems for Grades 9-12. Center for Middle Eastern Studies, 56-76 link: https://resources.aldaad.org/resources/africa-enslaved-a-curriculum-unit-on-comparative-slave-systems-for-grades-9-12/

Bakker, P. (2004). Creole Studies in the 21st century: A brief presenytation of the special issue on Creole languages. Acta Linguistica Hafniensia, 1-10.

Bakker, P., \& Daval-Markussen, A. (2004). Abrief presentation of the special issue on creole languages. Creole studies in the 21st century, 141150. DOl:https://doi.org/10.1075/ jpcl.26.1.02bak

Bonenfant, J. (2011). History of Haitian-Creole: From Pidgin to Lingua Franca and English Inflñuence on the Language. Review of Higher Education and Self-Learning, 4(11), 27-34.

Chaudenson, R. (1979). Les Creoles Français. Paris: Fernand Nathan.
Degraff, M. (2005). The Fallacy of Creole Exceptionalism. Linguistics Most Dangerous Myth, 34(4), 533-591 DOl: https://doi.org/10.1017/ S0047404505050207

Dejean, Y. (2015, JUNE 16). Diglossia Revisited: French and Creole in Haiti. Journal Homepage, 34(3), 189-212 DOl: 10. 1080/00437956.1983.11435744

Doucet, R. (2011, Juillet 14). Haiti, Quisqueya ou Bohio: Commment donc appeler. AlterPresse.

Hebblethwaite, B. (2012). French and Underdevelopment, Haitian Creole and Develoment: Educational Language Policy Problems and Solutions in HAITI. Journal of Pidgin and Creole Languages, 27(2), 255-302. DOl:https://doi. org/10.1075/jpcl.27.2.03heb.

Hispaniola. (2017, September 6). Encyclopaedia Britannica. (E. Britannica, Producer, \& Encyclopaedia Britannica) Retrieved August 2020, from Encyclopaedia Britannica: https:// www.britannica.com/place/Hispaniola

Holmes, J. (2013). An introduction to Sociolinguistics. London \& New York: Routledge.

Manning, P. (1992). Slavery And African Life. Journal of Social History, 
25(3), 647-649 DOl: https://doi. org/10.1353/jsh/25.3.647

Pieter, M., \& Norval, S. (1986). Substrata versus Universals in Creole Genesis. Amsterdam : John Benjamins Publishing.

Spears, A., \& Berotte , C. (2012). The Haitian Creole Language: History, Structure, Use, and Education. New York: Lexington Books.

Spears, A., \& Berotte Joseph, C. (2010). The Haitian Creole Language History, Structure, Use, and Education. New York, New York, United Sta- tes: ROWMAN \& LITTLEFIELD. USAID. (2018, March). Haiti Staple Food Market Fundamentales. Retrieved from Fews NET: https://reliefweb.int/sites/reliefweb.int/ files/resources/Haiti\%20MFR_final_20180326\%20\%281\%29.pdf?platform=hootsuite Uzo, M. (2016). Haiti History: Spanish Discovery and Colonization, French Colonialism, Society, Economy, Government, Politics. CreateSpace Independent Publishing Platform. 